\title{
The zircon petrochronological record of a REE-enriched pegmatite and its source pluton in the Pikes Peak Batholith (Colorado, USA)
}

\author{
LUDMILA MARIA FONSECA TEIXEIRA, JULIEN \\ MARIUS ALLAZ, OLIVIER BACHMANN AND JÖRN- \\ FREDERIK WOTZLAW
}

ETH Zürich

Presenting Author: ludmila.fonseca@erdw.ethz.ch

Pegmatites are complexly zoned rocks that are generally considered to have crystallised from highly evolved granitic melts, but their sources and conditions of formation remain unclear. Some of their typical characteristics suggest precipitation from fluids rich in flux elements $(\mathrm{B}, \mathrm{C}, \mathrm{F}, \mathrm{Cl}, \mathrm{P})$, and the stage at which the system transitions from melt- to fluiddominated crystallisation is poorly understood. In order to shed some light on this melt-to-fluid dominated transition and to establish a timescale for the crystallisation of the whole system, we analysed the trace-element compositions and the age of zircons from the border zone of the Big Bertha pegmatite and its host syenogranite within the Pikes Peak Batholith (Colorado, USA), a $\sim 1.1 \mathrm{Ga}$ anorogenic granitic body. The South Platte area in the northern part of the batholith contains over 50 REE-rich pegmatites. The NYF-type Big Bertha pegmatite consists of a fine-grained graphic granite border zone, a composite blocky quartz-microcline core and a late-stage REE-rich mineralisation including phases such as columbite, monazite, and samarskite(Y). Zircon grains from the border zone differ visually, texturally, and geochemically from the ones of the granite. Cathodoluminescence images show oscillatory zoning in the granite zircons and metamict textures in the pegmatite. High Ucontent (on the order of $10^{3}$ to $10^{4} \mathrm{ppm}$ ) in zircon from the pegmatite led to complete metamictization and associated extreme $\mathrm{Pb}$-mobilization, precluding accurate dating of these crystals. For the granite zircons, first CA-ID-TIMS data yielded a weighted mean ${ }^{206} \mathrm{~Pb} /{ }^{238} \mathrm{U}$ date of $1082.1 \pm 0.2 \mathrm{Ma}$. Inherited cores of ca. 1.7 and $1.4 \mathrm{Ga}$ were identified by LA-ICP-MS, suggesting contribution from the regional basement rocks. Trace element data in the pegmatite zircon grains are notably rich in $\mathrm{Y}$, Hf, $U$ and REE in comparison with the granite. Therefore, we suggest that these two sets of zircon grains record the system evolution from melt to fluid-rich, crystallising first the magmatic granitic zircons and then transitioning to a flux-rich fluid environment in which the pegmatite zircon grains precipitated. Further high-precision geochronology of the pegmatite mineralisation (monazite, columbite) will establish the temporal link between granite emplacement and pegmatite formation at the $\sim 100,000$ year level. 